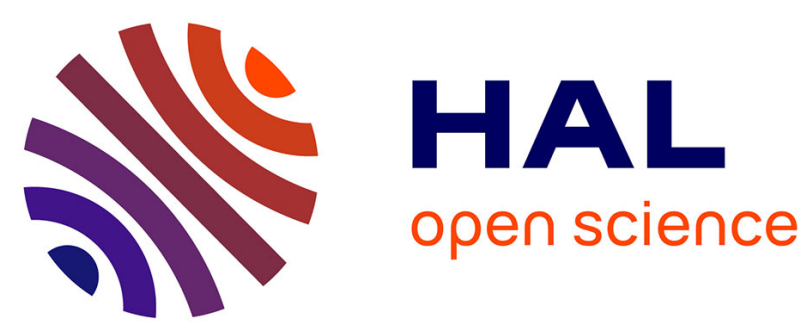

\title{
Influence of initial plant density on sawn timber properties for Douglas-fir (Pseudotsuga menziesii (Mirb.) Franco)
}

Andreas Rais, Werner Poschenrieder, Hans Pretzsch, Jan-Willem G van de Kuilen

\section{To cite this version:}

Andreas Rais, Werner Poschenrieder, Hans Pretzsch, Jan-Willem G van de Kuilen. Influence of initial plant density on sawn timber properties for Douglas-fir (Pseudotsuga menziesii (Mirb.) Franco). Annals of Forest Science, 2014, 71 (5), pp.617-626. 10.1007/s13595-014-0362-8 . hal-01102308

\section{HAL Id: hal-01102308 \\ https://hal.science/hal-01102308}

Submitted on 12 Jan 2015

HAL is a multi-disciplinary open access archive for the deposit and dissemination of scientific research documents, whether they are published or not. The documents may come from teaching and research institutions in France or abroad, or from public or private research centers.
L'archive ouverte pluridisciplinaire HAL, est destinée au dépôt et à la diffusion de documents scientifiques de niveau recherche, publiés ou non, émanant des établissements d'enseignement et de recherche français ou étrangers, des laboratoires publics ou privés. 


\title{
Influence of initial plant density on sawn timber properties for Douglas-fir (Pseudotsuga menziesii (Mirb.) Franco)
}

\author{
Andreas Rais • Werner Poschenrieder • Hans Pretzsch • \\ Jan-Willem G. van de Kuilen
}

Received: 13 August 2013/Accepted: 21 January 2014 /Published online: 14 February 2014

(C) INRA and Springer-Verlag France 2014

\begin{abstract}
- Context Mechanical wood properties are increasingly relevant for structural applications and are influenced by growing space availability. Douglas-fir (Pseudotsuga menziesii (Mirb.) Franco) has an increasing market share in Europe and is mainly processed to sawn timber.

- Aim A sample of 164 thinning trees was taken from two Douglas-fir long-term forestry research plots in Germany. The end-use quality of about 2,000 side and center boards was analyzed as a function of initial plant density $(1,000,2,000$, and 4,000 trees per hectare) and log position within the stem. - Methods Sawn timber quality was described by knottiness, density, modulus of elasticity, and strength. Explanatory parameters were radial position, longitudinal position, and initial plant density. All boards were strength graded visually and by the grading machine GoldenEye-706 using both X-rays for detecting densities and size as well as position of knots and
\end{abstract}

\section{Handling Editor: Jean-Michel Leban}

Contribution of the co-authors Jan-Willem G. van de Kuilen and Hans Pretzsch: initiated the project.

Andreas Rais: sampled the trees and analyzed the data.

Andreas Rais and Werner Poschenrieder: oversaw statistical analyses of the data.

Andreas Rais, Werner Poschenrieder, Hans Pretzsch, and Jan-Willem G. van de Kuilen: wrote the manuscript.

A. Rais $(\bowtie) \cdot J .-W$. G. van de Kuilen

Holzforschung München, Technische Universität München,

Winzererstrasse 45, 80797 Munich, Germany

e-mail: rais@hfm.tum.de

A. Rais $\cdot$ W. Poschenrieder $\cdot$ H. Pretzsch

Chair for Forest Growth and Yield Science, Technische Universität

München, Hans-Carl-von-Carlowitz-Platz 2, 85354 Freising,

Germany

J.-W. G. van de Kuilen

Faculty of Civil Engineering and Geosciences, TU Delft, Delft, The Netherlands laser interferometry for detecting eigenfrequency (DIN 4074, DIN 2012; EN 14081-2, CEN 2010).

- Results High plant density led to better mechanical sawn timber quality. Significant differences were especially observed between 1,000 and 2,000 trees per hectare. The yield of machine strength-graded center boards of strength class C24 increased from 50 to $89 \%$ at low and high initial plant density, respectively.

- Conclusion Foresters are able to improve end-product quality by controlling planting density in particular. The roundwood price that foresters get should be based on the proportion of higher strength classes within logs to give incentives for a more quality-oriented forest management.

Keywords Wood quality $\cdot$ Knottiness $\cdot$ Dynamic modulus of elasticity $\cdot$ Strength grading $\cdot$ Tensile strength $\cdot$ Board position

\section{Introduction}

Forest management of softwood has moved towards more integrated approaches that consider risks such as snow, storm, and bark beetles (Griess and Knoke 2011) and imply wider initial spacing (Smith and Reukema 1986; Hein et al. 2007). Silvicultural guidance to the forester usually aims to maximize volume yield and takes into account the multifunctionality of forests but pays little attention to the actual properties of the material produced. There are concerns that the relevance of timber quality might deteriorate in the future, and, as a consequence, a better understanding of the processes that control wood quality is required.

The second National Forest Inventory (NFI2 2005) has quantified the current area of Douglas-fir forests in Germany at about 180,000 ha, equalling a portion of $1.7 \%$ of forest area in Germany. The share of intensively managed forest stands of Douglas-fir has increased in Germany within the recent 
decades, particularly in the 1960s and 1970s. Due to this significant increase in planting, currently, many trees are considered as tree age class 2 (21-40 years) and class 3 (4160 years). As thinning takes place at these stands, an increasing amount of logs will come into the market. Most wood will be used as a structural material. The assessment of Douglas-fir timber quality in relation to forestry measures is increasingly considered as important (Hapla 1980; Sauter 1992). Naturally, the variance of the quality of Douglas-fir (sawn) timber is large: Douglas-fir coming from the original old-growth forests of western USA with low annual increment is superior with regard to wood quality compared to the fast-growing trees of modern-managed short-rotation forests (Constantino and Haley 1988; Barrett and Kellogg 1991). There are indications that the available forest resource of Douglas-fir timber has changed and has a negative impact on its strength and stiffness values (Dahlen et al. 2012).

Within the upstream section of the production chain, forest managers may take fundamental decisions for wood quality of Douglas-fir that are related to (1) site conditions (Kantavichai et al. 2010); (2) genetics, breeding, and selection (Vikram et al. 2011); and (3) silvicultural treatment (Robbins 2000; Weiskittel et al. 2006; Hein et al. 2008; Newton et al. 2012). Plant density in particular is a cost factor and has a significant influence on wood properties. For other softwoods, plant density determines the management of optimum wood quality at a considerable extent (Brazier and Mobbs 1993; Robbins 2000; Kang et al. 2004; Fujimoto and Koga 2009).

Wood processing may control the physical and mechanical properties of sawn timber through board position and sawing pattern (Lindström et al. 2009; Øvrum et al. 2011). Besides, timber quality of Douglas-fir can be nondestructively predicted by acoustic tools at the level of standing trees (Wagner et al. 2003; Amishev and Murphy 2008a), of logs (Amishev and Murphy 2008b; Rais et al. 2014), and of sawn timber (Dahlen et al. 2012). For structural use, timber quality is crucial and usually defined using indirect indicators such as a quality grade that mainly depends on knottiness or direct indicators such as density and stiffness (modulus of elasticity) which are predictors for strength. In particular, stiffness is a very important indicator for log and sawn wood quality for Douglas-fir (Dahlen et al. 2012). For Douglas-fir, modulus of elasticity in turn was most affected by timber density, less by knots or microfibril angle (Vikram et al. 2011). However, knottiness of sawn timber is a major criterion for timber grade assignment as it influences strength properties and size (including length) effects (Barrett and Fewell 1990; Denzler 2007; Rais et al. 2010; Stapel and van de Kuilen 2013). Additionally, national standards differ in the determination of static modulus of elasticity (random vs. systematic orientation) and complicate these dependencies.

Previous analyses of Douglas-fir often focused on tree or $\log$ level with regard to wood quality and did not continue as far as sawn timber quality and immediate quality parameters such as strength, stiffness, and knottiness of individual (Mitchell 1975; Carter et al. 1986; Todaro and Macchioni 2010; Klädtke et al. 2012). A general link between growth and wood properties of Norway spruce was made by Houllier et al. (1995). This knowledge was incorporated into stand growth models, economic analyses, and management tools to investigate the impact of silvicultural practices on standing yield and financial return (Mitchell 1988). In this empirical study, we want to make precise predictions on timber quality disregarding volume or economic aspects. Douglas-fir (Pseudotsuga menziesii (Mirb.) Franco) was selected as a model species, but the results are of general relevance for softwood management. For analysis, unique Douglas-fir plots of the long-term forestry research plots in Bavaria, Southern Germany were available which were established in the 1970s in order to comprehend the dependencies of growth on different spacing. The even-aged trees represent typical commercial thinning trees of a wide range of managed forests. The objectives were to (1) investigate the impact of space availability on mechanical properties of sawn timber and to (2) quantify the effect of space availability on sawn timber yield by strength grading. The quality of side and center boards was analyzed as a function of initial plant density and log position (axial and radial) in the stem.

\section{Material and method}

\subsection{Material}

A sample of 164 Douglas-fir trees (P. menziesii (Mirb.) Franco) was used in this investigation. The trees originated from two experimental site plots in Southern Germany which are part of the Bavarian network of long-term forestry research plots. One site is located in the north of Bavaria next to the city of Aschaffenburg in a low mountain range named Spessart. The other site is located about $15 \mathrm{~km}$ south of the city of Ansbach. Both experimental sites have been founded in the beginning of the 1970s. Hence, the age of all trees was about 40 years. Within the sample, all trees were typical thinning trees; future crop trees were not included. At both sites, the experimental area is divided into smaller single plots. These are square shaped with an edge length of $30 \mathrm{~m}$ and a buffer zone of $5 \mathrm{~m}$ around the plot. Initial plant density differs within the single plots $-1,000,2,000$, and 4,000 trees per hectare.

Thinning was performed in accordance to a standardized experimental program on the basis of a guide curve described by Klädtke et al. (2012). Thinning type is defined as a final crop-tree system; thinning frequency is determined by the dominant height. When dominant height reached $12 \mathrm{~m}, 150$ future crop trees were selected. The guide curve gives the number of trees per hectare depending on the dominant height. 
In the past, thinning followed this reference curve in the autumns/winters of 1989, 1994, 1999, 2004, and 2010. The sampled trees for this research were harvested for measurement in the winter of 2010. The trees - selected by foresterswere typical for thinning trees according to $\log$ quality and $\log$ dimensions.

Table 1 gives an overview of the samples. Logs of $4.1 \mathrm{~m}$ have been sawn to boards when the top diameter was at least $24 \mathrm{~cm}$ without bark. Logs have been sawn using a band saw, with sawing pattern shown in Fig. 1. It was tried to get as many center boards as possible with the preferred cross-section of $50 \mathrm{~mm} \times 150 \mathrm{~mm}(n=998)$ as this is a standard cross-section for both joists loaded in bending and for lamellas used in glued laminated timber production. Moreover, from the outer parts of the stems, a number of 936 side boards with cross-section of $30 \mathrm{~mm} \times 100 \mathrm{~mm}$ and $30 \mathrm{~mm} \times 140 \mathrm{~mm}$ could be obtained.

\subsection{Method}

Strength grading of sawn timber can be done visually as well as by machines. For visual grading, the German standard DIN 4074 (DIN 2012) is one of the most relevant in Central Europe (Stapel and Van de Kuilen 2013). The grading rules from this standard are for instance applied in countries like the Czech Republic, Austria, Italy, and Germany. The standard distinguishes 11 properties (knots, fissures, wane, rate of growth, slope of grain, pith, warp, and discoloration) for which classes are defined. The most important criterion for the mechanical properties of joists and edgewise-loaded boards is knottiness whereby the grade is normally determined by the single-knot value DEK. The knot value DEK is the major ratio of the minimal surface diameter of an oval knot to the side width of the board on which the knot is visible (DIN 4074, DIN 2012). Only the knot value DEK was taken into consideration when the boards were visually graded. Grades S13, S10, S7, and reject were evaluated. In EN 1912 (CEN 2012), grade S10 has been allocated into strength class C24 (Douglas-fir from Germany) according to EN 338 (CEN 2009a). Machine strength grading has been performed using GoldenEye-706 giving the dynamic modulus of elasticity (MOEdyn), a machine knot value, and a board density without knots calculated on X-ray picture of the board.

The bending strength of the boards was predicted using the machine data regarding knots, density, and MOEdyn. The boards were assigned to European strength classes C18, C24, C30, and C40 (EN 338, CEN 2009a). Every single-strength class was graded individually using the complete data (C18/reject, $\mathrm{C} 24 /$ reject, $\mathrm{C} 30 /$ reject, and $\mathrm{C} 40 /$ reject); no strength class combination was applied (ITT/100/10/08, CEN 2013). Strength class C40 was graded in order to find a possible relationship between initial plant density $(i P D)$ and high-quality timber. The other three classes were graded as they are the common strength classes used nowadays (EN 14081-4, CEN 2009b).

A number of 701 center boards were randomly selected and tested in tension according to EN 408 (CEN 2009c). All test pieces were of sufficient length $(4.1 \mathrm{~m})$ to provide a test length clear of the testing machine grips of nine times the larger cross-sectional dimension. From a preliminary test series, we found a constant ratio between tensile and bending strength of 0.71 for all $i P D s$, thus covering the whole sawfalling range of wood qualities. Therefore, it is possible to use tensile strength as a measure for comparison also with literature presenting bending strength data.

\subsection{Statistical analysis}

Sawn timber quality $y$ was described by the following variables: visual knottiness, machine knottiness, density,
Table 1 Sampled data, mean values, and standard deviation in brackets

\begin{tabular}{|c|c|c|c|c|c|}
\hline & & & \multicolumn{3}{|c|}{ Initial plant density $i P D$ (trees $\mathrm{ha}^{-1}$ ) } \\
\hline & & & $1,000(\mathrm{SD})$ & $2,000(\mathrm{SD})$ & $4,000(\mathrm{SD})$ \\
\hline Plots & Number of single plots & & 11 & 14 & 8 \\
\hline \multirow[t]{4}{*}{ Trees } & Number & - & 64 & 68 & 32 \\
\hline & DBH & $\mathrm{mm}$ & $330(68)$ & $316(56)$ & $305(35)$ \\
\hline & Height & $\mathrm{dm}$ & $255(42)$ & $270(24)$ & $268(22)$ \\
\hline & Height to DBH & $\mathrm{cm} \mathrm{cm}^{-1}$ & $79(15)$ & $88(11)$ & $88(9)$ \\
\hline \multirow[t]{2}{*}{ Logs } & Number & - & 135 & 151 & 68 \\
\hline & Middle diameter & $\mathrm{mm}$ & $285(57)$ & $274(46)$ & $262(30)$ \\
\hline \multirow[t]{3}{*}{ Center boards } & Number & - & 409 & 423 & 166 \\
\hline & Cross-section & $\mathrm{mm}^{2}$ & & $50 \times 150$ & \\
\hline & Board length & $\mathrm{mm}$ & $4,089(149)$ & $4,102(24)$ & $4,106(11)$ \\
\hline \multirow[t]{3}{*}{ Side boards } & Number & - & 407 & 377 & 152 \\
\hline & Cross-section & $\mathrm{mm}^{2}$ & \multicolumn{3}{|c|}{$30 \times 100,30 \times 140$} \\
\hline & Board length & $\mathrm{mm}$ & $4,071(174)$ & 4,091 (49) & $4,100(47)$ \\
\hline
\end{tabular}




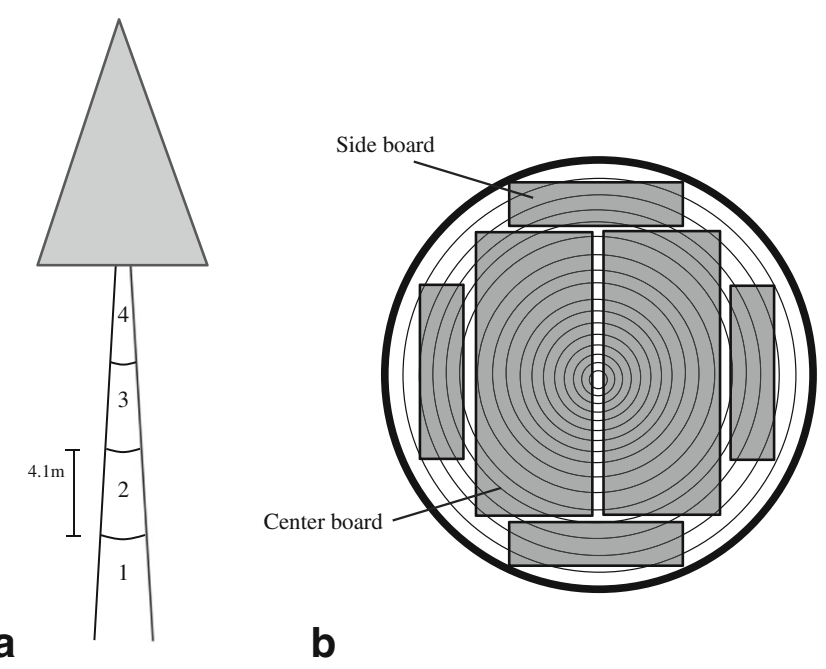

Fig. 1 Origin and location of boards in longitudinal direction (a) and radial direction (b); center boards were cut out from the inner part, side boards from the outer part of the logs

MOEdyn, estimated bending strength, and measured tensile strength. An analysis was performed to verify whether sawn timber quality $y$ is related to any of the following explanatory variables: $i P D$, radial position $(r p)$, and longitudinal position $(l p)$.

The model to be fitted was then formulated as follows:

$y_{i j k l}=a_{0}+a_{1} r p+a_{2} l p+a_{3} i P D+b_{i}+b_{i j}+b_{i j k}+b_{i j l k}+\varepsilon$

where $i$ was the site index; $j$ indexed the plot in site $i ; k$ indexed the tree on plot $j$ in site $\mathrm{i} ; l$ indexed the $\log$ of tree $k$ on $\operatorname{plot} j$ in site $i$; and $a_{0}, a_{1}, a_{2}$, and $a_{3}$ were the fixed effect coefficients to be estimated. The explanatory variables $i P D$ (levels-1,000, 2,000 , and 4,000 trees per hectare), $l p$ (levels - 1 for butt log, 2 for second $\log , 3$ for third $\log$, and 4 for top $\log$ ), and $r p$ (levels - center and side boards) were of categorical type and were dummy-coded; the reference was a main board from the butt log of a tree coming from a plot with an $i P D$ of 1,000 trees per hectare.

Aside from these fixed effects, a set of random effects was considered to match the error structure of the data. Parameters $b_{i}, b_{i j}, b_{i j k}$, and $b_{i j l k}$ were nested random effects at site, plot-insite, tree-in-plot-in-site, and log-in-tree-in-plot-in-site levels (Pinheiro and Bates 2000; Zuur et al. 2009). The random effects were assumed to be normally distributed with zero mean and constant variance. These nesting level-specific variances were estimated during the model fitting process. The symbol $\varepsilon$ represented the independent and identically distributed random errors.

The Akaike information criterion (AIC) was used as fitting criterion for selecting the best multiple linear model (Burnham and Anderson 2002). By means of AIC, a manual model simplification procedure was carried out to obtain the adequate model and to remove nonsignificant parameters. The AIC values were calculated, and the model with the lowest AIC was selected and used for further analysis. It was tested whether this model performed better than a model including only random effects.

All data were analyzed using R (R Development Core Team 2012) and the R package lme4 (Bates and Maechler 2009) and languageR (Baayen 2008). The default behavior of lmer to optimize the restricted maximum likelihood criterion (REML) was used (Pinheiro and Bates 2000). Normality and homogeneity have been checked by visual inspections of plots of residuals against fitted values.

\section{Results}

\subsection{Overview of data}

There was a large degree of variation in all physical and mechanical sawn timber properties which required powerful statistical analyses. Timber quality varied between $i P D$. Table 2 illustrates the differences for relevant parameters of sawn timber quality. Trees growing up at high plant density were characterized by better timber properties. The knottiness of boards was lowest for $i P D$ of 4,000 trees per hectare. Density, dynamic MOEdyn, and strength of boards increased with increasing $i P D$. For comparison purposes, some timber quality properties are mentioned from the literature in order to give a framework of reference. These values were determined by small, defect-free specimens and cannot be directly compared to our sawn timber values. In average, wood density of Douglas-fir was given as $0.5 \mathrm{~g} / \mathrm{cm}^{3}$, static bending modulus of elasticity as $12,500 \mathrm{~N} / \mathrm{mm}^{2}$, bending strength as $85 \mathrm{~N} / \mathrm{mm}^{2}$, and tensile strength as $95 \mathrm{~N} / \mathrm{mm}^{2}$ (Göhre 1958; Knigge 1958; Forest Products Laboratory 1999).

\subsection{Statistical dependencies between timber properties} and spacing as well as stem position

As described within Section 2, all possible combinations of the explanatory variables $r p, l p$, and $i P D$ were scrutinized with respect to their effect on sawn timber properties. Models were preferred which provided the lowest AICs. Generally, the models used in our analysis performed better than the according models that included only random effects. Timber quality describing parameters - knottiness (either visual or by machine), density, MOEdyn, estimated strength, and tensile strength - were best explained by all three predictors $(r p, l p$, and $i P D)$. Although the trees originated from two different plots in Southern Germany, site was not of much relevance.

The $r p$ has significant influence if the center and side boards were compared: boards sawn from the outer part of 
Table 2 Sawn timber properties depending on $i P D$, mean value, standard deviation in brackets

\begin{tabular}{|c|c|c|c|c|c|c|}
\hline & & & & \multicolumn{3}{|c|}{ Initial plant density $i P D\left(\right.$ trees $\left.\mathrm{ha}^{-1}\right)$} \\
\hline & & & & $1,000(\mathrm{SD})$ & 2,000 (SD) & 4,000 (SD) \\
\hline \multirow[t]{6}{*}{ Center board } & Knottiness & DIN 4074, DEK $^{\mathrm{a}}$ & - & $0.53(0.18)$ & $0.47(0.15)$ & $0.42(0.16)$ \\
\hline & & Machine & - & $2,639(497)$ & $2,312(519)$ & $2,126(491)$ \\
\hline & Density & & $\mathrm{kg} \mathrm{m}^{-3}$ & $461(42)$ & $466(43)$ & $474(42)$ \\
\hline & MOEdyn & & $\mathrm{N} \mathrm{mm}^{-2}$ & $10,509(1,898)$ & $11,805(2,291)$ & $12,578(2,232)$ \\
\hline & Estimated bending strength & & $\mathrm{N} \mathrm{mm}^{-2}$ & $24.3(10.3)$ & $31.5(11.5)$ & $35.8(10.6)$ \\
\hline & Tensile strength ${ }^{\mathrm{a}}$ & & $\mathrm{N} \mathrm{mm}^{-2}$ & $17.3(6.9)$ & $22.5(9.2)$ & $25.7(7.7)$ \\
\hline \multirow[t]{6}{*}{ Side board } & Knottiness & DIN 4074, DEK & - & - & - & - \\
\hline & & Machine & - & $2,421(616)$ & $1,979(631)$ & $1,684(568)$ \\
\hline & Density & & $\mathrm{kg} \mathrm{m}^{-3}$ & $494(44)$ & $504(44)$ & $511(47)$ \\
\hline & MOEdyn & & $\mathrm{N} \mathrm{mm}^{-2}$ & $11,622(2,171)$ & $13,443(2,640)$ & $14,327(2,605)$ \\
\hline & Estimated bending strength & & $\mathrm{N} \mathrm{mm}^{-2}$ & $32.4(10.5)$ & $41.5(11.7)$ & $46.1(11.0)$ \\
\hline & Tensile strength & & $\mathrm{N} \mathrm{mm}^{-2}$ & - & - & - \\
\hline
\end{tabular}

${ }^{\text {a }}$ Knottiness according DIN 4074 (DEK) and tensile strength were only determined on a smaller sample size: 92, 311, and 98 in increasing order of $i P D$

the stem were characterized by higher quality (see Table 3); knottiness was lower, density $\left(35 \mathrm{~kg} / \mathrm{m}^{3}\right)$, MOEdyn $(1,513 \mathrm{~N} /$ $\left.\mathrm{mm}^{2}\right)$, and estimated bending strength $\left(9.6 \mathrm{~N} / \mathrm{mm}^{2}\right)$ were higher.

Along the height of the tree $(l p)$, Douglas-fir showed decreasing sawn timber quality. Sawn timber from a height of about $11 \mathrm{~m}$ above ground $(l p=3)$ had a significantly lower $\left(-21 \mathrm{~kg} / \mathrm{m}^{3}\right.$, Table 3$)$ density $\left(444 \mathrm{~kg} / \mathrm{m}^{3}\right)$ than sawn timber from the butt $\log \left(465 \mathrm{~kg} / \mathrm{m}^{3}\right)$. There was also a difference in MOEdyn and strength of sawn timber between the different longitudinal positions in the stem. Sawn timber MOEdyn from a butt $\log (l p=1)$ was $507 \mathrm{~N} / \mathrm{mm}^{2}$ higher than from the fourth $\log (l p=4)$; estimated bending strength was $5.1 \mathrm{~N} / \mathrm{mm}^{2}$ higher. The measured tensile strength of $l p=3$ was $2.5 \mathrm{~N} / \mathrm{mm}^{2}$ lower than that of $l p=1$ (see Table 3).

High $i P D$ improved timber strength properties positively (see Table 3). Except for wood density, all other properties were significantly different between $i P D=1,000$ and $i P D=$ 2,000 trees per hectare as well as between $i P D=1,000$ and $i P D=4,000$ trees per hectare. The differences between $i P D=$ 2,000 and $i P D=4,000$ trees per hectare were not significant at a probability level of 0.05 . Knottiness - visual and machinesignificantly decreased with $i P D$ for both kinds of boards. The parameter MOEdyn - as one of the best predictors for strength - was positively affected by $i P D$. For estimated and measured strength, similar results were observed. For instance, tensile strength values increased by about $6 \mathrm{~N} / \mathrm{mm}^{2}$ when $i P D$ was doubled from 1,000 to 2,000 trees per hectare. There was only a slight, but not significant, difference of tensile strength between trees growing in density of $i P D=$ 2,000 and $i P D=4,000$ trees per hectare. Table 4 shows the yield for different grades depending on the $i P D$. Only boards of the butt logs were considered. The kind of grading- whether visual or machine grading - did not influence the general trend: Yields were the highest for boards cut from trees with high $i P D$ for all strength classes. For instance, none of the center boards from trees growing up at $i P D=1,000$ reached $\mathrm{C} 40$, and only $10 \%$ of the center boards of the lowest $i P D$ class met the requirements of $\mathrm{C} 30$; yield rose to threefold, i.e., $32 \%$ for $i P D=4,000$. The yield of machine-graded center boards in $\mathrm{C} 24$ rose by about $40 \%$ from the lowest (50\%) to the highest ( $89 \%) i P D$. Side board yield also achieved higher levels for each grade. It increased from 84 to $99 \%$ for side boards of grade $\mathrm{C} 24$. The yield of visually graded timber from $i P D=4,000$ was more than twice as high as from $i P D=1,000$. In comparison to machine-graded timber, visually graded timber reached only half the yield. For Douglas-fir, visual grading seems to be not efficient (Roblot et al. 2008).

\section{Discussion}

\subsection{High variation of timber quality of Douglas-fir}

The sampled wood represented young thinning trees of log dimensions which were usually sawn to structural timber. The low quality was partly caused by the age of 40 years and the high proportion of juvenile timber; for Douglas-fir, about the 20th ring approximates the point of transition from juvenile to mature wood based on the pattern of pith-to-bark wood density (DiLucca 1989; Barrett and Kellogg 1991; Kennedy 1995). Juvenile wood is characterized by a lower percentage of late wood, lower density, shorter tracheids with larger microfibril angle and grain angle, and consequently lower strength and stiffness properties (Bendtsen 1978). Glos et al. (2006) used a very similar material in a study of Douglas-fir in 
Table 3 Effect of radial position $(r p)$, longitudinal position (lp), and $i P D$ on sawn timber properties regarded as knottiness, density, MOEdyn, and strength

\begin{tabular}{|c|c|c|c|c|c|c|c|}
\hline & & \multicolumn{2}{|l|}{ Knottiness } & \multirow{2}{*}{$\begin{array}{l}\text { Density } \\
\mathrm{kg} \mathrm{m}^{-3}\end{array}$} & \multirow{2}{*}{$\begin{array}{l}\text { MOEdyn } \\
\mathrm{N} \mathrm{mm}^{-2}\end{array}$} & \multirow{2}{*}{$\begin{array}{l}\text { Estimated bending } \\
\text { strength } \\
\mathrm{N} \mathrm{mm}^{-2}\end{array}$} & \multirow{2}{*}{$\begin{array}{l}\text { Tensile } \\
\text { strength } \\
\mathrm{N} \mathrm{mm}^{-2}\end{array}$} \\
\hline & & $\begin{array}{l}\text { Visual } \\
-\end{array}$ & $\begin{array}{l}\text { Machine } \\
-\end{array}$ & & & & \\
\hline \multirow[t]{2}{*}{$a_{0}$} & & 0.51 & 2,501 & 465 & 10,588 & 25.5 & 19.1 \\
\hline & & 0.03 & 61 & 7 & 323 & 1.3 & 1.1 \\
\hline \multirow[t]{4}{*}{$a_{1}, r p$} & Center & & $-\mathrm{a}$ & $-\mathrm{a}$ & $-\mathrm{a}$ & $-\mathrm{a}$ & \\
\hline & Board & & - & - & - & - & \\
\hline & Side & & $-308 b$ & $+35 \mathrm{~b}$ & $+1,513 b$ & $+9.6 \mathrm{~b}$ & \\
\hline & Board & & 21 & 1 & 68 & 0.4 & \\
\hline \multirow[t]{8}{*}{$a_{2}, l p$} & 1 & $-\mathrm{a}$ & $-\mathrm{a}$ & $-\mathrm{a}$ & $-\mathrm{a}$ & $-\mathrm{a}$ & $-\mathrm{a}$ \\
\hline & & - & - & - & - & - & - \\
\hline & 2 & +0.003 a & $+146 \mathrm{~b}$ & $-14 b$ & $-90 \mathrm{ac}$ & $-0.9 b$ & $-1.4 b$ \\
\hline & & 0.014 & 27 & 2 & 96 & 0.5 & 0.6 \\
\hline & 3 & $+0.069 \mathrm{~b}$ & $+286 \mathrm{c}$ & $-21 c$ & $-509 b$ & $-3.4 c$ & $-2.5 b$ \\
\hline & & 0.019 & 39 & 2 & 142 & 0.7 & 0.8 \\
\hline & 4 & $+0.036 a b$ & $+391 \mathrm{c}$ & $-24 c$ & $-507 b c$ & $-5.1 \mathrm{c}$ & $-1.9 a b$ \\
\hline & & 0.030 & 72 & 4 & 252 & 1.3 & 1.3 \\
\hline \multirow[t]{6}{*}{$a_{3}, i P D$} & 1,000 & $-\mathrm{a}$ & $-\mathrm{a}$ & $-\mathrm{a}$ & $-\mathrm{a}$ & $-\mathrm{a}$ & $-\mathrm{a}$ \\
\hline & & - & - & - & - & - & - \\
\hline & 2,000 & $-0.06 b$ & $-394 b$ & $+19 b$ & $+1,909 \mathrm{~b}$ & $+9.2 b$ & $+6.2 \mathrm{~b}$ \\
\hline & & 0.02 & 76 & 9 & 410 & 1.7 & 1.4 \\
\hline & 4,000 & $-0.10 b$ & $-507 b$ & $+13 \mathrm{ab}$ & $+1,944 b$ & $+10.4 \mathrm{~b}$ & $+7.1 \mathrm{~b}$ \\
\hline & & 0.03 & 89 & 10 & 486 & 2.0 & 1.7 \\
\hline$b_{\mathrm{i}}$ & $\sigma^{2}$ & $0.76 \times 10^{-3}$ & $1.0 \times 10^{3}$ & 15 & $0.3 \times 10^{5}$ & 0.0 & 0.0 \\
\hline$b_{\mathrm{ij}}$ & $\sigma^{2}$ & $1.33 \times 10^{-3}$ & $14.5 \times 10^{3}$ & 186 & $3.8 \times 10^{5}$ & 5.9 & 3.7 \\
\hline$b_{\mathrm{ijk}}$ & $\sigma^{2}$ & $0.98 \times 10^{-3}$ & $61.8 \times 10^{3}$ & 1,031 & $25.4 \times 10^{5}$ & 43.8 & 23.5 \\
\hline$b_{\mathrm{ijk} 1}$ & $\sigma^{2}$ & $1.84 \times 10^{-3}$ & $10.8 \times 10^{3}$ & 52 & $2.0 \times 10^{5}$ & 3.2 & 4.0 \\
\hline$\varepsilon$ & $\sigma^{2}$ & $21.7 \times 10^{-3}$ & $202.5 \times 10^{3}$ & 517 & $21.3 \times 10^{5}$ & 64.6 & 36.6 \\
\hline$n$ & & 701 & 1,934 & 1,934 & 1,934 & 1,934 & 701 \\
\hline
\end{tabular}

Within a category $r p, l p$, and $i P D$, numbers within the same column are significantly different at the 0.05 probability level if they are different in all letters (a-c); standard errors in italics

Germany, and found a mean tensile strength of $24.5 \mathrm{~N} / \mathrm{mm}^{2}$ and a mean MOEdyn of $12,400 \mathrm{~N} / \mathrm{mm}^{2}(n=315)$. Sauter (1992), on the other hand, used for his investigation about 100 -year-old trees from Germany with higher sawn timber quality and took a sample of 250 boards that had a mean MOEdyn of about $15,000 \mathrm{~N} / \mathrm{mm}^{2}$ (our sample-12,100 N/ $\mathrm{mm}^{2}$ ) and a mean tensile strength of over $42 \mathrm{~N} / \mathrm{mm}^{2}$ (our sample $-20.8 \mathrm{~N} / \mathrm{mm}^{2}$, only main boards). The stiffness and strength properties of this study apparently represented the lower tail of the distribution of mechanical properties.

\subsection{Influence of radial and longitudinal board position} on wood quality

The results showed a consistent effect of the distance to pith on all mechanical properties studied. Side boards were of higher quality than center boards. The estimated bending strength of side boards was almost $10 \mathrm{~N} / \mathrm{mm}^{2}$ higher than that of center boards and hence immediately affected sawn timber yield. Our result went in line with Glos et al. (2006) who separated their sample into boards with and without pith: Tensile strength of boards with pith was $21.5 \mathrm{~N} / \mathrm{mm}^{2}$ as compared to $27.6 \mathrm{~N} / \mathrm{mm}^{2}$, and MOEdyn was $11,500 \mathrm{~N} / \mathrm{mm}^{2}$ as compared to $13,400 \mathrm{~N} / \mathrm{mm}^{2}$. Previous investigations confirmed the change of timber characteristics in radial direction: for sawn timber of Norway spruce (Brüchert et al. 2000; Oscarsson et al. 2011) and for small, defect-free specimens of young Douglas-fir (Langum et al. 2009).

In general, sawn timber quality of Douglas-fir decreased with increasing distance to ground (Knigge 1958; Barrett and Kellogg 1991). We observed a gradual decline of MOEdyn with increasing longitudinal position that was also reported by 
Table 4 Sawn timber yield (in percent) of boards depending on iPD, only boards from butt logs

\begin{tabular}{|c|c|c|c|c|c|}
\hline & \multirow[t]{2}{*}{ Grading } & \multirow[t]{2}{*}{ Strength class } & \multicolumn{3}{|c|}{$\begin{array}{l}\text { Initial plant density } i P D \\
\left(\text { trees } \mathrm{ha}^{-1}\right)\end{array}$} \\
\hline & & & 1,000 & 2,000 & 4,000 \\
\hline \multirow[t]{11}{*}{ Yield (\%) } & \multicolumn{5}{|c|}{ Center board } \\
\hline & Visual & $\mathrm{S} 10+(\mathrm{C} 24)$ & 26 & 35 & 54 \\
\hline & Machine & $\mathrm{C} 18$ & 83 & 93 & 99 \\
\hline & & $\mathrm{C} 24$ & 50 & 73 & 89 \\
\hline & & $\mathrm{C} 30$ & 10 & 29 & 32 \\
\hline & & $\mathrm{C} 40$ & 0 & 2 & 4 \\
\hline & \multicolumn{5}{|l|}{ Side board } \\
\hline & \multirow[t]{4}{*}{ Machine } & $\mathrm{C} 18$ & 96 & 98 & 100 \\
\hline & & $\mathrm{C} 24$ & 84 & 95 & 99 \\
\hline & & $\mathrm{C} 30$ & 33 & 66 & 77 \\
\hline & & $\mathrm{C} 40$ & 1 & 7 & 14 \\
\hline
\end{tabular}

Langum et al. (2009). Similar height-dependent MOEdyn patterns were also observed for Scots pine (Lindström et al. 2009) and for Norway spruce (Brüchert et al. 2000). However, in our analysis, the difference was low between boards cut out from butt and second log. The significant difference was about $500 \mathrm{~N} / \mathrm{mm}^{2}$ between MOEdyn of the butt $\log$ and the third log. Sawn timber density got lower with increasing height position and confirmed results of Barrett and Kellogg (1991) who studied second-growth Douglas-fir $2 \times 4$ lumber from 46 to 60 years. Strength behaved in accordance to Langum et al. (2009) - decreasing strength values with increasing vertical position within a tree-although they investigated clear (defect free) wood specimens.

\subsection{Influence of initial plant density on wood quality}

Initial plant density $i P D$ had significant influence on sawn timber quality for structural use. Within an $i P D$ range of $1,000,2,000$, and 4,000 trees per hectare, it clearly determined knottiness, density, MOEdyn, and strength. For all strength classes under consideration, the highest plant density achieved the highest yield. Previous studies assessed wood quality at the stage of logs and showed that $i P D$ was an important factor which affected the size of branches (Brazier and Mobbs 1993), specifically in the butt and second log of Douglas-fir (Robbins 2000). Pfister et al. (2007) also found a positive correlation between the largest branch diameter of log and initial density in a 33-year-old Norway spruce plantation in southern Sweden. The added value of this study was that it clearly demonstrated the dependence of sawn timber quality on $i P D$ both for center and side boards: It confirmed that knottiness decreases with increasing $i P D$ and at the same time proves that MOEdyn and strength both increase. Some research has also been conducted in previous work on stiffness of structural timber, but quantitative data is limited: Based on Norway spruce in Sweden, Johansson (1992) concluded that the quality of machine stress-graded timber (deflection) increased in response to a decrease in spacing. For Sitka spruce, increased planting distances influenced stiffness properties of sawn timber (measured by a deflection grading machine) negatively (Brazier and Mobbs 1993). In our study, also wood density increased with $i P D$, albeit not consistently and only from 1,000 to 2,000 trees per hectare at a significance level of 0.05 . This was in accordance to the findings of Johansson (1993) who reported a significant but only small effect of little practical importance for a Norway spruce stand of similar age and structure. Fujimoto and Koga (2009) reported also on an unclear dependency between initial spacing and wood density of 22-year-old larch, but they observed that closer spacing results in a faster increase in wood density from the pith outward than for more widely spaced trees. They concluded that initial plant density directly influences the age of transition from juvenile to mature wood. Low planting distances had also a negative influence on the proportion of juvenile wood of Sitka spruce (Brazier and Mobbs 1993).

In terms of quality, the ideal silviculture suggests high stand density management. Nevertheless, foresters have not reacted noticeably to these findings because of higher costs involved in increasing initial stocking, the extra thinning which may be required, and the additional rotation age. The results of this study give foresters the option not to focus on the optimization of volume alone (current practice) but also on that of wood quality. In practice, however, foresters barely participate on the added end-product value. As foresters are paid by product volume and not by sawn wood quality, there is no direct need for foresters to improve their operations such that higher wood qualities are obtained. Logs grading is also promising, but logs are valued mainly on the basis of volume and not on the basis of the wood quality sawn from them. Sawn timber of high-strength classes achieve higher prices on the market, and sawmills are able to estimate the end-product quality as well as the value very accurately by machine strength grading. This knowledge could be considered in the current roundwood pricing system to give incentives for a more quality-oriented forest management.

4.4 Limitations of the transferability to other softwood species and to older trees

Wood density of other conifer species such as spruce or pine is likely to depend on $i P D$ in the same manner as that of Douglasfir: for all conifers, high $i P D s$ result in low radial growth rates, the proportion of latewood within annual rings increases, and finally wood density increases (Kollmann 1951), but probably the presence of juvenile wood obscures this rule. The dependencies between $i P D$ and the other sawn timber properties can 
be transferred to both conifers and deciduous trees, as growing patterns are similar with respect to space availability: The $i P D$ influences the branchiness of trees and consequently the knottiness of boards that affects mechanical properties directly, because wood fibers are deviated by local defects as knots. Larger knots cause higher timber grain deviation, a lower stiffness and especially lower strength. For Douglas-fir, wood density seems to explain timber properties as stiffness and strength more accurately than microfibril angle (Lachenbruch et al. 2010; Vikram et al. 2011) or knottiness (Vikram et al. 2011). Even though some literature emphasized that density is more important than knottiness with respect to mechanical properties, our research indicated that this is only valid for modulus of elasticity, but clearly not important for tensile strength of structural size of Douglas-fir. Our investigation confirmed that MOEdyn showed a stronger dependency on density $\left(r^{2}=0.52\right)$ than on machine knottiness $\left(r^{2}=0.37\right)$ for all 1,934 boards. The $r^{2}$ between tensile strength and density was 0.18 and between tensile strength and knottiness was $0.39(n=$ 701). Timber quality of larger (older) Douglas-fir trees is likely to depend on $i P D$ as competition prevails and is likely to exert continuous and positive influence on the yield of high-quality boards due to wood density as well as thickness of branches and knots. The dependence of wood quality on $I P D$ is evident for the lower part of the stem in particular. Hence, it may be expected to even persist far beyond the juvenile phase of stand development to the stage of final cutting.

\section{Conclusion}

The analysis aimed to contribute to the facilitation of a production chain that ranges from the management of softwood forests to the decision making of sawmills. It clearly demonstrated that foresters can influence end-product quality by controlling initial space availability of trees. The sample represented young thinning trees of an age of 40 years whose logs were mostly processed to sawn timber. The study showed that increased radial and decreased axial position of the boards strongly determined mechanical sawn timber properties positively. A high initial number of trees per hectare resulted in lower knottiness, higher timber density, and higher stiffness and strength. The influence on boards' knottiness, MOEdyn, and strength was observed in particular between an initial plant density of 1,000 and 2,000 as well as 1,000 and 4,000 trees per hectare.

Our findings provide additional facts that help to derive the appropriate stand density in order to put into effect a specific management objective. Many long-term spacing and thinning experiments showed that a stand density reduction below 20 $30 \%$ of the maximum stand density can severely reduce the mean annual increment and total volume yield of forest stands (Pretzsch 2005). Wide spacing and early thinning, on the other hand, can significantly accelerate diameter growth and shorten the rotation period. The findings that wood quality reductions are associated with low densities provide new arguments for keeping higher density levels for achieving both high-quality and quantity of wood production. Future forest management plans should provide a balanced mixture of strategies concerning wood quality and volume as well as risk management on the level of stands.

Our results call into question a low-density management on fertile sites in particular where growth rates are high a priori, and strong thinning results in even higher growth rates, wider tree rings, lower wood density, and severe yield reduction. On poor sites, in contrast, the effect of thinning on quantity and quality of wood production might be less disadvantageous. Future evaluations can be based on the shown trade-off between density and wood quality in order to weigh and optimize the pros and cons of density management by integration into exiting growth models and scenario analyses.

Information about treatment effects on quality and quantity of the produced timber in a given stand development phase or even over the whole rotation were so far nearly missing. Thus, an overarching optimization of ecological, production, and economical results of Douglas-fir management in forest practice was not possible. This will be remedied when the revealed relationship between stand density management and sawn timber properties of Douglas-fir will be integrated in individual tree growth models. This enables scenario analyses about the effect of stand density on a broad range of output variables including wood quality and quantity. Here, we provide the indispensable knowledge for such a model completion. In contrast to the quickly changing technical and economical frame conditions, the revealed between-tree and within-tree wood allocation patterns are time invariant and indispensable for further evaluations of treatment effects at tree and stand level. To our state of knowledge, the analyzed Douglas-fir stands are the only available samples of this species in Europe where both timber quantity and quality have been recorded since stand establishment and provide a unique database for model development and calibration. Finally, further investigations should focus on older (future) trees or model the quality development with increasing tree age. However, due to the reduced knottiness and its positive influence of the yield of side boards, it is likely that high initial plant density also promotes timber quality of larger trees.

Acknowledgments The wood was kindly sponsored by the Bayerischen Staatsforsten, sawn at sawmill Försch/Bavaria, and strength graded by Schwörer Haus KG/Germany. MiCROTEC and Martin Bacher are thanked for their support during grading. Thanks are also due to Ulricke Nickles, Johanna Lintl, Marcus Schild, Xiaohe Kang, Stefan Torno, Johannes Wurster, Heribert Bergmeier, Eva Bossert, Johannes Försch, Stefan Seifert, Martin Nickel, Thomas Zimmerer, Ralf 
Polzer, and the students of the Fachoberschule Triesdorf for the fieldwork, to Ulrich Kern for the graphical artwork, to Peter Biber for checking the statistical analysis, and to the anonymous reviewers for their constructive criticism.

Funding We thank the Bavarian State Ministry for Nutrition, Agriculture, and Forestry for the support of the project X36 supervised by Robert Morigl.

\section{References}

Amishev D, Murphy GE (2008a) Preharvest veneer quality evaluation of Douglas-fir stands using time-of-flight acoustic technique. Wood Fiber Sci 40:587-598

Amishev D, Murphy GE (2008b) In-forest assessment of veneer grade Douglas-fir logs based on acoustic measurement of wood stiffness. For Prod J 58:42-47

Baayen RH (2008) Analyzing linguistic data: a practical introduction to statistics. Cambridge University Press, Cambridge, p 390

Barrett JD, Fewell AR (1990) Size factors for the bending and tension strength of structural lumber. Proc. CIB-W18 Meet. 23

Barrett JD, Kellogg RM (1991) Bending strength and stiffness of secondgrowth Douglas-fir dimension lumber. For Prod J 41:35-43

Bates DM, Maechler M (2009) lme4: Linear mixed-effects models using S4 classes. R Packag. version 0.999375-32

Bendtsen AB (1978) Properties of wood from improved and intensively managed trees. For Prod J 28:61-72

Brazier JD, Mobbs ID (1993) The influence of planting distance on structural wood yields of unthinned Sitka spruce. Forestry 66:333352. doi:10.1093/forestry/66.4.333

Brüchert F, Becker G, Speck T (2000) The mechanics of Norway spruce [Picea abies (L.) Karst]: mechanical properties of standing trees from different thinning regimes. For Ecol Manag 135:45-62

Burnham KP, Anderson DR (2002) Model selection and multi-model inference: a practical information-theoretic approach, 2nd ed., Springer, 488

Carter RE, Miller IM, Klinka K (1986) Relationships between growth form and stand density in immature Douglas-fir. For Chron 62:440 445. doi:10.5558/tfc62440-5

CEN (2009a) EN 338:2009, structural timber - strength classes, European Committee for Standardization, Brussels

CEN (2009b) EN 14081-4, Timber structures — strength graded structural timber with rectangular cross section-part 4: machine gradinggrading machine settings for machine controlled systems, European Committee for Standardization, Brussels

CEN (2009c) EN 408:2009, Timber structures - structural timber and glued laminated timber - determination of some physical and mechanical properties, European Committee for Standardization, Brussels

CEN (2010) EN 14081-2, Timber structures - strength graded structural timber with rectangular cross section - part 2: machine grading; additional requirements for initial type testing, European Committee for Standardization, Brussels

CEN (2012) EN 1912, Structural timber - strength classes - assignment of visual grades and species, European Committee for Standardization, Brussels

CEN (2013) ITT/100/10/08, Initial type testing report, TC124/TG1, Table 10-13, model given in TG1/0209/03, European Committee for Standardization, Brussels

Constantino LF, Haley D (1988) Trends in wood quality for the British Columbia coast and the United States, Pacific Northwest, Westside. For Sci 34:176-189

Dahlen J, Jones PD, Seale RD, Shmulsky R (2012) Bending strength and stiffness of in-grade Douglas-fir and southern pine no. $22 \times 4$ lumber. Can J For Res 42:858-867. doi:10.1139/x2012-041
Denzler JD (2007) Modellierung des Größeneffektes bei biegebeanspruchtem Fichtenschnittholz. 166

R Development Core Team (2012) The R project for statistical computing

DiLucca CM (1989) Juvenile-mature wood transition. In: Kellogg RM (ed), Second growth Douglas-fir its manag. and conversion for value. Special Publication, Forintek, Canada Crop., Vancouver, 173, pp 59-65, SP-32

DIN (2012) DIN 4074-1, Strength grading of wood - coniferous sawn timber

Forest Products Laboratory (1999) Wood handbook — wood as an engineering material. General technical report, U.S. Department of Agriculture, Forest Service, Forest Products Laboratory, Madison 463

Fujimoto T, Koga S (2009) An application of mixed-effects model to evaluate the effects of initial spacing on radial variation in wood density in Japanese larch (Larix kaempferi). J Wood Sci 56:7-14. doi:10.1007/s10086-009-1045-1

Glos P, Richter C, Diebold R (2006) Maschinelle Sortierung von Brettern aus den Holzarten Lärche und Douglasie. Holzforsch München 134

Göhre K (1958) Die Douglasie und ihr Holz. 595

Griess VC, Knoke T (2011) Growth performance, windthrow, and insects: meta-analyses of parameters influencing performance of mixed-species stands in boreal and northern temperate biomes. Can J For Res 41:1141-1159. doi:10.1139/x11-042

Hapla F (1980) Untersuchung der Auswirkung verschiedener Pflanzverbandsweiten auf die Holzeigenschaften der Douglasie. Dissertation an der Forstlichen Fakultät der Universität Göttingen. 182

Hein S, Mäkinen H, Yue C, Kohnle U (2007) Modelling branch characteristics of Norway spruce from wide spacings in Germany. For Ecol Manag 242:155-164. doi:10.1016/j.foreco.2007.01.014

Hein S, Weiskittel AR, Kohnle U (2008) Effect of wide spacing on tree growth, branch and sapwood properties of young Douglas-fir (Pseudotsuga menziesii (Mirb.) Franco) in south-western Germany. Eur J For Res 127:481-493. doi:10.1007/s10342-008-0231-9

Houllier F, Leban J-M, Colin F (1995) Linking growth modelling to timber quality assessment for Norway spruce. For Ecol Manag 74: 91-102. doi:10.1016/0378-1127(94)03510-4

Johansson K (1992) Effects of initial spacing on the stem and branch properties and graded quality of Picea abies (L.) Karst. Scand J For Res 7:503-514. doi:10.1080/02827589209382743

Johansson K (1993) Influence of initial spacing and tree class on the basic density of Picea abies. Scand J For Res 8:18-27. doi:10.1080/ 02827589309382752

Kang K-Y, Zhang SY, Mansfield SD (2004) The effects of initial spacing on wood density, fibre and pulp properties in jack pine (Pinus banksiana Lamb.). Holzforschung. doi: 10.1515/HF.2004.069

Kantavichai R, Briggs D, Turnblom E (2010) Modeling effects of soil, climate, and silviculture on growth ring specific gravity of Douglasfir on a drought-prone site in Western Washington. For Ecol Manag 259:1085-1092. doi:10.1016/j.foreco.2009.12.017

Kennedy RW (1995) Coniferous wood quality in the future: concerns and strategies. Wood Sci Technol 29:321-338

Klädtke J, Kohnle U, Kublin E et al (2012) Wachstum und Wertleistung der Douglasie in Abhängigkeit von der Standraumgestaltung. Schweiz Z Forstwes 163:96-104. doi:10.3188/szf.2012.0096

Knigge W (1958) Untersuchungen über die Beziehungen zwischen Holzeigenschaften und Wuchs der Gastbaumart Douglasie. Schriftenr. der Forstl. Fak. der Univ. Göttingen und Mitteilungen der Niedersächsischen Forstl. Versuchsanstalt, Band 20. Sauerländer, Frankfurt a. M., p 101

Kollmann F (1951) Technologie des Holzes und der Holzwerkstoffe, 2nd edn. Springer, Berlin

Lachenbruch B, Johnson GR, Downes GM, Evans R (2010) Relationships of density, microfibril angle, and sound velocity with stiffness and strength in mature wood of Douglas-fir. Can J For Res 40:55-64. doi:10.1139/X09-174

Langum CE, Yadama V, Lowell EC (2009) Physical and mechanical properties of young-growth Douglas-fir and western hemlock from western Washington. For Prod J 59:37-47 
Lindström H, Reale M, Grekin M (2009) Using non-destructive testing to assess modulus of elasticity of Pinus sylvestris trees. Scand J For Res 24:247-257. doi:10.1080/02827580902758869

Mitchell KJ (1975) Dynamics and simulated yield of Douglas-fir. For Sci Monograph 17:1-39

Mitchell KJ (1988) Sylver: modeling the impact of silviculture on yield, lumber value, and economic return. For Chron 64:127-131

Newton M, Lachenbruch B, Robbins JM, Cole EC (2012) Branch diameter and longevity linked to plantation spacing and rectangularity in young Douglas-fir. For Ecol Manag 266:75-82. doi:10.1016/j. foreco.2011.11.009

NFI2 (2005) Die zweite Bundeswaldinventur-BWI 2, Der Inventurbericht, 2005.412 Bundesministerium für Ernährung. Landwirtschaft und Verbraucherschutz, Bonn

Oscarsson J, Olsson A, Johansson M et al (2011) Strength grading of narrow dimension Norway spruce side boards in the wet state using first axial resonance frequency. Int Wood Prod J 2:108-114. doi:10. 1179/2042645311Y.0000000015

Øvrum A, Vestøl GI, Høibø OA (2011) Modeling the effects of timber length, stand, and tree properties on grade yield of Picea abies timber. Scand J For Res 26:99-109. doi:10.1080/02827581.2010.534110

Pfister O, Wallentin C, Nilsson U, Ekö P-M (2007) Effects of wide spacing and thinning strategies on wood quality in Norway spruce (Picea abies) stands in southern Sweden. Scand J For Res 22:333343. doi: $10.1080 / 02827580701504951$

Pinheiro J, Bates D (2000) Mixed-effects models in S and S- PLUS. 528

Pretzsch H (2005) Stand density and growth of Norway spruce (Picea abies (L.) Karst.) and European beech (Fagus sylvatica L.): evidence from long-term experimental plots. Eur J For Res 124:193205. doi:10.1007/s10342-005-0068-4

Rais A, Stapel P, van de Kuilen GJ-W (2010) Assessment of local timber defects during testing and grading as influenced by machine approval procedure. Proc. WCTE 2010, Riva del Garda, Italy

Rais A, Pretzsch H, van de Kuilen J-WG (2014) Roundwood pre-grading with longitudinal acoustic waves for production of structural boards. Eur J Wood Wood Prod 72:87-98. doi:10.1007/s00107-013-0757-5
Robbins JM (2000) Influence of spacing and crown recession on wood quality of intensively-managed young growth Douglas-fir. M.S. thesis, Department of Forest Products and Department of Forest Science, Oregon State University, Corvallis, p 105

Roblot G, Coudegnat D, Bleron L, Collet R (2008) Evaluation of the visual stress grading standard on French spruce (Picea excelsa) and Douglas-fir (Pseudotsuga menziesii) sawn timber. Ann For Sci 65: 812. doi:10.1051/forest:2008071

Sauter UH (1992) Technologische Holzeigenschaften der Douglasie als Ausprägung unterschiedlicher Wachstumsbedingungen. Dissertation, Universität Freiburg. 221

Smith JHG, Reukema DL (1986) Effects of plantation and juvenile spacing on tree and stand development. In: Oliver CD, Hanley DP, Johnson JA (eds) Douglas-fir Stand Manag. Futur. College of forest resources. University of Washington, Seattle, pp 239245

Stapel P, van de Kuilen GJ-W (2013) Efficiency of visual strength grading of timber with respect to origin, species, cross section, and grading rules: a critical evaluation of the common standards. Holzforschung 1-14. doi: 10.1515/hf-2013-0042

Todaro L, Macchioni N (2010) Wood properties of young Douglas-fir in Southern Italy: results over a 12-year post-thinning period. Eur J For Res 130:251-261. doi:10.1007/s10342-010-0425-9

Vikram V, Cherry ML, Briggs D et al (2011) Stiffness of Douglas-fir lumber: effects of wood properties and genetics. Can J For Res 41: 1160-1173. doi:10.1139/x11-039

Wagner FG, Gorman TM, Wu SY (2003) Assessment of intensive stresswave scanning of Douglas-fir trees for predicting lumber MOE. For Prod J 53:36-39

Weiskittel AR, Maguire DA, Monserud RA et al (2006) Intensive management influence on Douglas-fir stem form, branch characteristics, and simulated product recovery. $\mathrm{N} \mathrm{Z} \mathrm{J} \mathrm{For}$ Sci 36:293-312

Zuur AF, Ieno EN, Walker N, et al. (2009) Mixed effects models and extensions in ecology with R. doi: 10.1007/978-0-38787458-6 